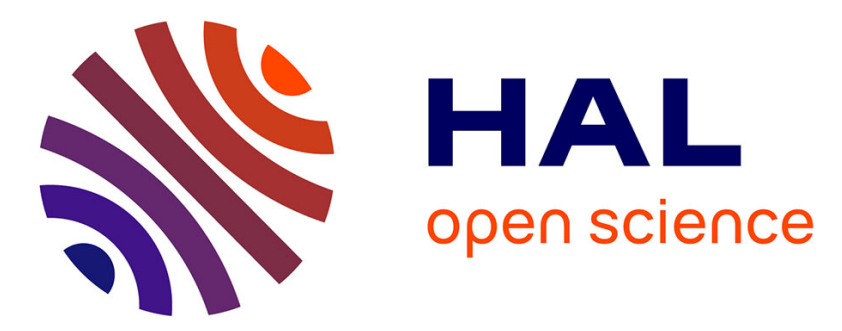

\title{
Selective isomerization-carbonylation of a terpene trisubstituted double bond
}

Hanna Busch, Florian Stempfle, Sandra Hess, Etienne Grau, Stefan Mecking

\section{To cite this version:}

Hanna Busch, Florian Stempfle, Sandra Hess, Etienne Grau, Stefan Mecking. Selective isomerizationcarbonylation of a terpene trisubstituted double bond. Green Chemistry, 2014, 16 (10), pp.4541-4545. $10.1039 / \mathrm{c} 4 \mathrm{gc} 01233 \mathrm{j}$. hal-01366463

\section{HAL Id: hal-01366463 https://hal.science/hal-01366463}

Submitted on 22 Nov 2019

HAL is a multi-disciplinary open access archive for the deposit and dissemination of scientific research documents, whether they are published or not. The documents may come from teaching and research institutions in France or abroad, or from public or private research centers.
L'archive ouverte pluridisciplinaire HAL, est destinée au dépôt et à la diffusion de documents scientifiques de niveau recherche, publiés ou non, émanant des établissements d'enseignement et de recherche français ou étrangers, des laboratoires publics ou privés. 


\section{Selective isomerization-carbonylation of a terpene trisubstituted double bond

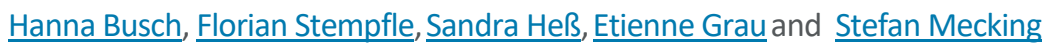

\section{Abstract}

Selective catalytic carbonylation of the trisubstituted double bond of citronellic acid is enabled via an isomerizationfunctionalization approach. Alkoxycarbonylation with $\left[\left\{1,2-\left({ }^{t} \mathrm{Bu}_{2} \mathrm{PCH}_{2}\right)_{2} \mathrm{C}_{6} \mathrm{H}_{4}\right\} \mathrm{Pd}(\mathrm{OTf})_{2}\right]$ as a catalyst precursor occurs with $>97 \%$ selectivity for the terminal diester dimethyl-3,7-dimethylnonane-dioate. This prevails much over the typical cationic methoxyaddition. The reactive primary carboxy group formed allows for e.g. the preparation of the high molecular weight novel polyester poly[3,7-dimethylnonanediyl-3,7-dimethylnonanedioate].

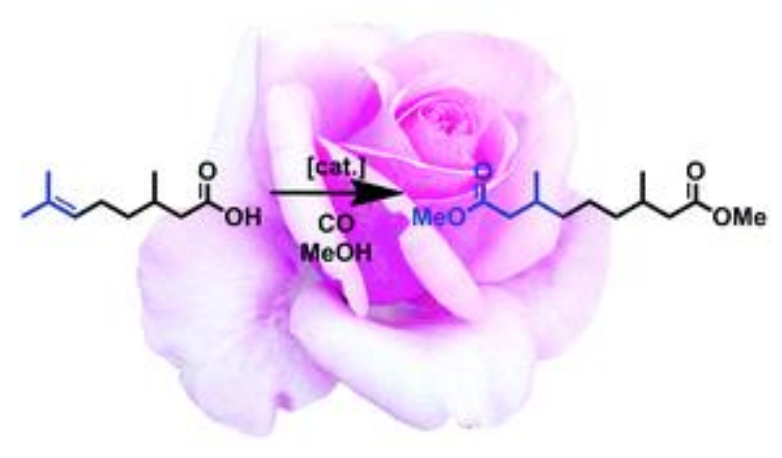

\section{Introduction}

A generation of functional groups by transition metal catalyzed carbonylation of double bonds is well established. A prominent example is hydroformylation, the largest scale application of homogeneous catalysis. $\stackrel{1}{\text { However, catalytic }}$ carbonylation reactions are limited to terminal double bonds of 1-olefins and the $n, m$-disubstituted double bonds of internal olefins $\mathrm{R}^{1}-\mathrm{CH}=\mathrm{CH}-\mathrm{R}^{2}$. Trisubstituted double bonds are not amenable to carbonylation and usually remain intact in hydroformylation and alkoxycarbonylation reactions of various substrates. 2,3 Only a carbocation reactivity is exploited synthetically as illustrated by Koch carbonylation of isobutene to pivalic acid derivatives. ${ }^{4}$

Additionally, in hydroformylation of substrates already bearing a functional carboxy group or other carbonyl groups, the $\alpha, \beta$-unsaturated compound formed by isomerization is prone to double bond hydrogenation, which is the major side reaction if not the predominant pathway.

However, a functionalization via catalytic carbonylation of trisubstituted double bonds would be desirable as they occur in many substrates of interest. This includes naturally occurring renewable compounds like terpenes, and also compounds formed by cracking of crude oil considered as waste streams today, 2-methyl-but-2-ene being the simplest representative.

We report on a selective catalytic carbonylation of a trisubstituted double bond, by means of an isomerizationfunctionalization ${ }^{5,6}$ approach that enables reaction at a more reactive position. As a model substrate, we chose citronellic acid, a terpene, $-\underline{7}$ that is accessible via direct oxidation of citronellol, a major component of geranium and rose oils..- This substrate features a functional group already in the starting material, which can be an additional challenge.

\section{Results and discussion}


Our anticipated approach ideally requires a single catalyst capable of carbonylation and extensive isomerization at the same time, which is also sufficiently reactive towards trisubstituted olefins. Cationic Pd(II) catalysts modified by bulky substituted electron-rich diphosphines can promote the selective conversion of disubstituted double bonds deep in a linear chain to a terminal ester group.., 9

For our studies, we employed perhaps the most prominent of these diphosphines, 1,2-bis(ditertbutylphosphino)xylene ${ }^{10}(\mathrm{dtbpx})$, in the form of the single component catalyst precursor [(dtbpx)Pd(OTf)](OTf). ${ }^{9}$

Exposure of a methanol solution of citronellic acid to carbon monoxide pressure in the presence of catalytic amounts of [(dtbpx)Pd(OTf)](OTf) (citronellic acid/Pd = 250) resulted in virtually complete conversion of the starting material under appropriate conditions $\left(80^{\circ} \mathrm{C}, 30 \mathrm{bar}, 4\right.$ days). Of the various conceivable methoxycarbonylation products - at the three terminal carbon atoms as well as at six internal carbon atoms - only dimethyl-3,7dimethylnonanedioate $(\mathbf{2}, \underline{\text { Scheme } 1)}$ ) is formed nearly exclusively $(>95 \%)$. The only other diester observed $(<2 \%)$ is dimethyl 3-(4-methylpentyl)pentanedioate (3) (Fig. 2, top, cf. ESI $\_$for identification of products). Within the accuracy of detection $(<0.1 \%)$, no secondary esters at internal carbon atoms are formed. As the only side reaction, hydromethoxylation to form 7-methoxy-3,7-dimethyloctanoate (4) is observed.<smiles>CC(C)=CCC[C@@H](C)CC(=O)O</smiles>

1
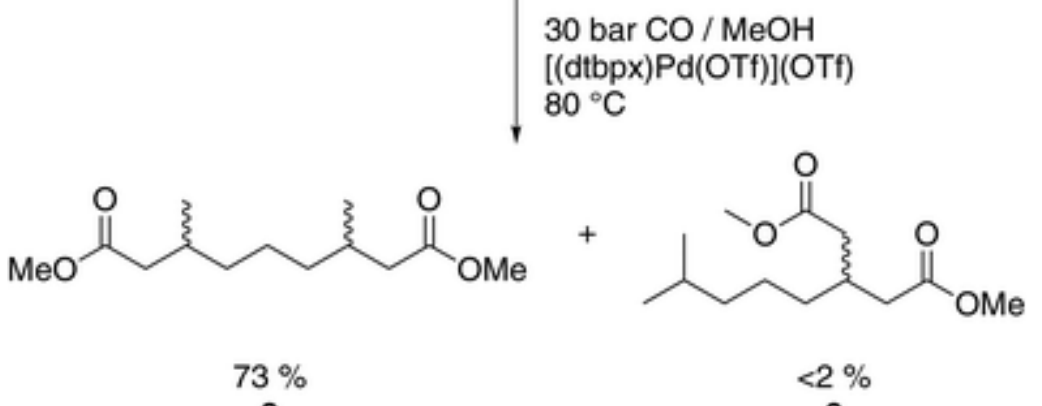

Scheme 1 Esters formed during the isomerizing methoxycarbonylation of citronellic acid.

Notably, isomerization of the double bond of the starting material 1 occurs rapidly even at room temperature, such that already in the initial stages of the carbonylation reaction all double bond isomers serve as a starting material. Within the distribution of isomers found, the thermodynamically most stable $\alpha, \beta$-unsaturated ester 3,7-dimethyloct-2enoate $\mathbf{5}$ prevails during the whole isomerization-carbonylation process. From the formation of the diester $\mathbf{2}$ over time it is evident that all isomers are amenable to carbonylation (Fig. 1). This shows that the much preferred formation of $\mathbf{2}$ over $\mathbf{3}$ is not due to a closer vicinity of the terminal methyl group to the double bond in the original starting material (1), but due to an intrinsically higher reactivity vs. the methyl group adjacent to the $-\mathrm{CH}_{2} \mathrm{COOR}$ functional group. All carbon atoms are accessible in principle, as the metal center 'runs' along the substrate to form all conceivable metal alkyl intermediates. 


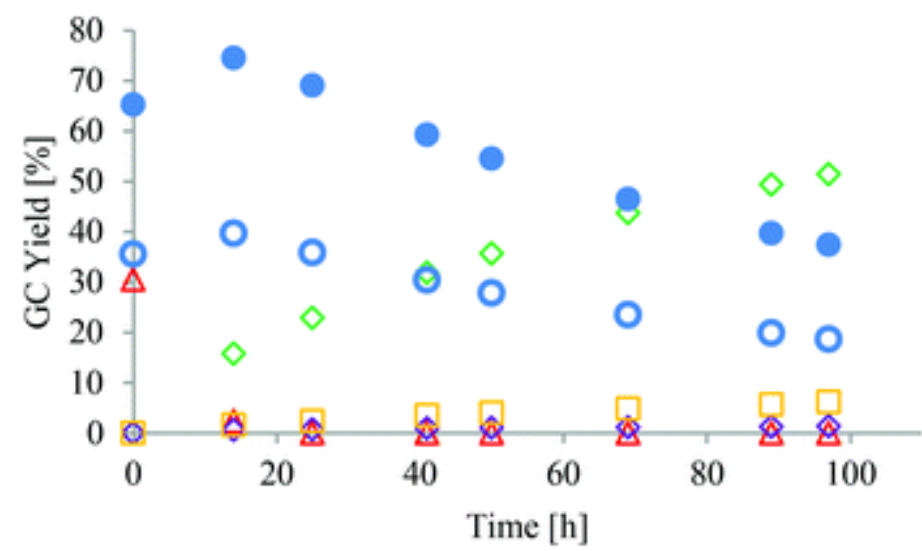

Fig. 1 Time dependent formation of the diesters $\mathbf{2} \diamond$ and $\mathbf{3} \diamond$ and the hydromethoxylated product $\mathbf{4} \square$ as well as the time dependent formation and consumption of the starting material $\mathbf{1} \Delta$, the main double bond isomer $5 \circ$ and all isomers thereof (including 5) 9 , at $70^{\circ} \mathrm{C}$ and 20 bar $\mathrm{CO}$. The overall yields in comparison with Table 1 were lower due to the loss of pressure while taking the samples during the reaction.

The diester $\mathbf{2}$ contains two stereocenters, consequently a preferred formation of one diastereomer could be possible in principle. As expected from the rather remote position of the site of carbonylation from the $-\mathrm{C}^{*}\left(\mathrm{CH}_{3}\right) \mathrm{CH}_{2} \mathrm{COOR}$ stereocenter in the starting material - five carbon atoms - no stereopreference is observed and the 2-rac and 2meso are formed in a 1:1 ratio. Note that the citronellic acid starting material is racemic (but would be racemized in any case by the isomerization, for experimental details $c f$. ESI $\_$).

A study of the impact of reaction conditions (Table 1) showed that the yield of the diester (2) increased with increasing temperature from $60^{\circ} \mathrm{C}$ to $80^{\circ} \mathrm{C}$ due to an increased reaction rate, but at higher temperatures yields decrease, likely due to catalyst deactivation (20 bar CO; entries 1-3, 7 and 10, Table 1). Under these conditions the initial rate of formation of $\mathbf{2}$ is $\mathrm{ca} .3 \mathrm{TO} \mathrm{h}^{-1}$. The CO pressure has a moderate impact on the product distribution, but at $90{ }^{\circ} \mathrm{C}$ methoxy-addition to 4 can be suppressed to a significant extent in favour of the desired diester (2) by increased $\mathrm{CO}$ concentrations (entries 6 to 9). Note that 4 could potentially be recycled to olefinic starting material by methanol elimination. ${ }^{11}$ Reaction on a larger scale than these screening experiments, starting from $0.1 \mathrm{~mol}(16.3 \mathrm{~g})$ of citronellic acid at 30 bar $\mathrm{CO}$ and $80^{\circ} \mathrm{C}$ leads to comparable product distributions and GC-yields (76\%) of 2.

Table 1 Methoxycarbonylation of citronellic acid catalyzed by [(dtbpx)Pd(OTf)](OTf) $\underline{a}$

\begin{tabular}{|c|c|c|c|c|c|c|}
\hline \multirow[b]{2}{*}{ Entry } & \multirow[b]{2}{*}{ Pressure [bar] } & \multirow[b]{2}{*}{ Temperature $\left[{ }^{\circ} \mathrm{C}\right]$} & \multicolumn{4}{|c|}{ Product distribution $\underline{\underline{b}}$ [\%] } \\
\hline & & & 2 & 3 & 4 & 5 and isomers ${ }^{c}$ \\
\hline 1 & 20 & 60 & 56 & 1 & 3 & 35 \\
\hline 2 & 20 & 70 & 68 & 2 & 6 & 19 \\
\hline 3 & 20 & 80 & 73 & 2 & 13 & 10 \\
\hline 4 & 30 & 80 & 73 & 2 & 12 & 10 \\
\hline 5 & 40 & 80 & 72 & 2 & 12 & 11 \\
\hline 6 & 10 & 90 & 54 & 2 & 21 & 19 \\
\hline 7 & 20 & 90 & 60 & 2 & 19 & 16 \\
\hline 8 & 30 & 90 & 66 & 2 & 14 & 8 \\
\hline 9 & 40 & 90 & 75 & 2 & 13 & 7 \\
\hline 10 & 20 & 100 & 68 & 3 & 13 & 12 \\
\hline
\end{tabular}

a Reaction conditions: 6 mmol citronellic acid, $24 \mu \mathrm{mol}$ (0.4 mol\%) [(dtbpx)Pd(OTf)](OTf), $10 \mathrm{~mL} \mathrm{MeOH,} \mathrm{4-5} \mathrm{d.} \mathrm{b} \mathrm{Values}$ are based on the percentage area from the gas chromatographic analysis of the crude reaction mixture. $c$ Virtually no starting material (1) remains. 
Although methoxycarbonylation selectivity is extremely high, we further studied carbonylation of citronellic acid with the catalyst precursor [(dadpx) $\mathrm{Pd}(\mathrm{OTf})](\mathrm{OTf})$ (dadpx $\left.=1,2-\left(\mathrm{CH}_{2} \mathrm{P}(1 \text {-adamantyl })_{2}\right)_{2} \mathrm{C}_{6} \mathrm{H}_{4}\right)$. In isomerizing methoxycarbonylation of methyl oleate, selectivity is significantly enhanced $v s$. the dtbpx analog, corresponding to a reduction of the branched side products to half $(4 \%$ vs. $9 \%$, at the same time the rate of isomerizing carbonylation is ca. 3-fold lower). $\underline{\underline{12}}$ However, carbonylation of citronellic acid occurred significantly slower than with [(dtbpx)Pd(OTf)](OTf), and results in an increased formation of methoxyaddition side product (1: 0\%; 2: 24\%; 3: 1\%; 4: 18\%; 5 and isomers: $55 \%$ ).

To underline the reactivity of the primary ester formed, polycondensation of the diester $\mathbf{2}$ was studied. Such stepgrowth reactions require high functional group conversions and very pure monomers to yield any substantial molecular weight. Isolation from the reaction mixture from carbonylation and purification yielded $\mathbf{2}$ in $>99 \%$ purity (Fig. 2, bottom).

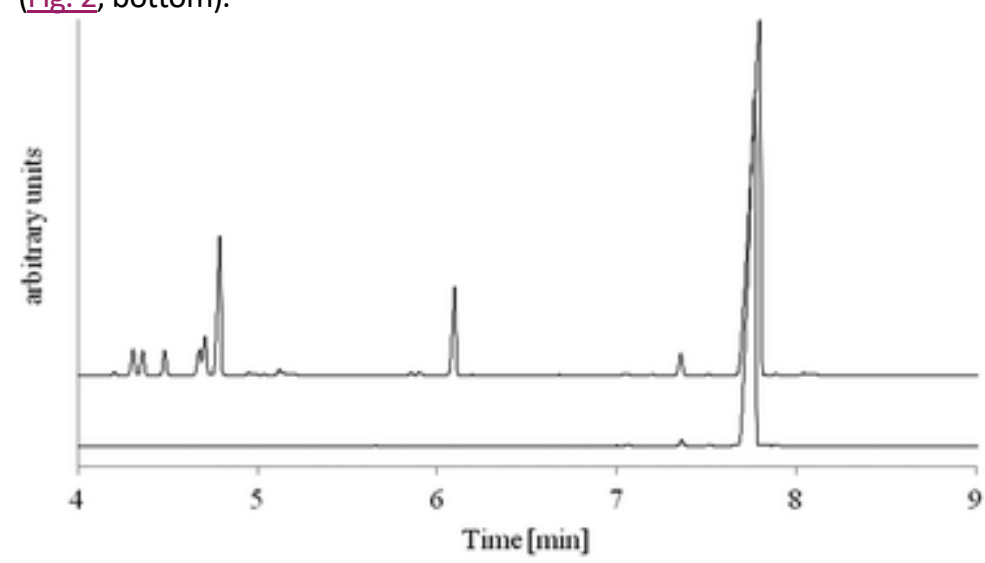

Fig. 2 Comparison of the gas chromatograms of the crude reaction mixture (top) obtained in the isomerizing methoxycarbonylation of citronellic acid with [(dtbpx)Pd(OTf)](OTf) (citronellic acid/Pd = 250, $4 \mathrm{~d}, 30 \mathrm{bar} \mathrm{CO}, 80^{\circ} \mathrm{C}$ ), and after column chromatography (bottom).

In order to obtain the analogous citronellic acid-based diol, the diester $\mathbf{2}$ was reduced $\underline{13}$ to yield the diol $\mathbf{6}$ in high yields and $>99 \%$ purity after workup by column chromatography.

Polycondensation of $\mathbf{2}$ and $\mathbf{6}$ (ratio $1: 1.1)$ catalyzed by titanium(IV)butoxide afforded the novel polyester poly[1,9(3,7-dimethyl)nonadiyl-1,9-(3,7-dimethyl)nonanedioate] (7) (Scheme 2).
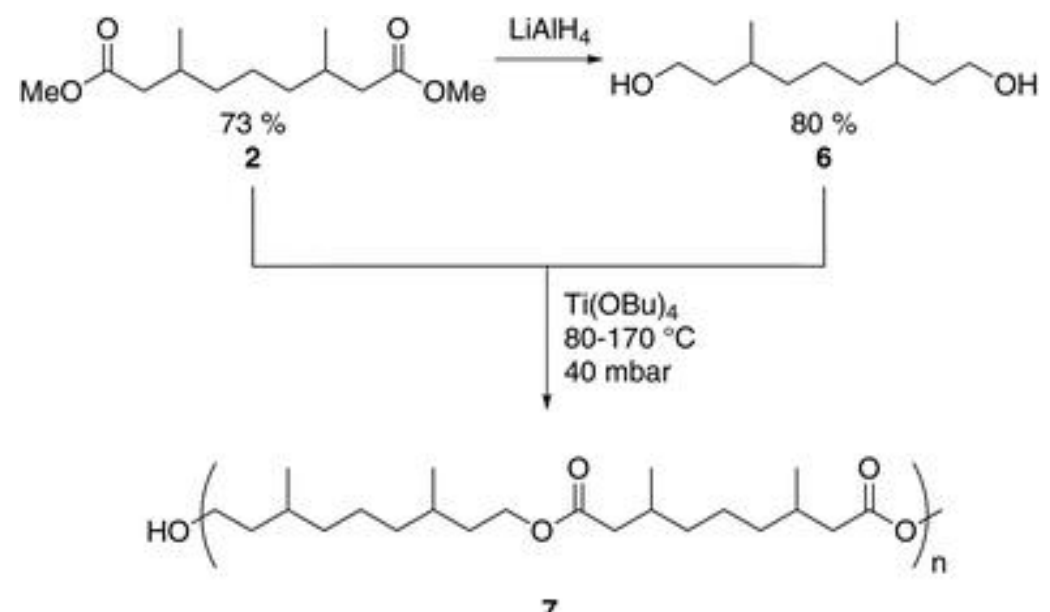

7

Scheme 2 Difunctional compounds from citronellic acid and their polymerization.

Indeed GPC reveals high molecular weights $\left(M_{n}\right)$ of typically $10^{4} \mathrm{~g} \mathrm{~mol}^{-1}\left(M_{\mathrm{w}} / M_{\mathrm{n}} \approx 3.0\right)$. These apparent molecular weights from GPC are confirmed by ${ }^{1} \mathrm{H}$ NMR end group analysis $\left(M_{\mathrm{n}}=0.9-1.4 \times 10^{4} \mathrm{~g} \mathrm{~mol}^{-1}\right)$ (for details $c f$. ESI $\_$). As expected due to the branched nature of the repeat units which impede crystallization, the novel polyester is an amorphous soft material. A glass transition was observed by DSC at $-57^{\circ} \mathrm{C}$. 


\section{Conclusions}

In summary, a selective catalytic carbonylation of trisubstituted double bonds is enabled for the first time by an isomerization-carbonylation approach. Although the reaction is rather slow to date, this catalytic functionalization predominates over the typical carbocationic methoxy-addition. The symmetric diester is obtained with an overall yield of $75 \%$. Reactive primary (novel) diesters are generated. Such a functionalization of usually unreactive highly substituted double bonds opens new avenues for the utilization of renewable resources and waste streams.

\section{Materials and methods}

\section{Materials}

Unless stated otherwise, all manipulations were carried out under an inert gas atmosphere using standard Schlenk or glovebox techniques. Methanol was distilled from magnesium turnings and iodine. Prior to use, technical grade petrolether ( $\mathrm{PE}$, boiling range 30 to $70^{\circ} \mathrm{C}$ ) and technical grade dichloro methane (DCM) were distilled. All other solvents were used in technical grade as received. Carbon monoxide (3.7) was supplied by Air Liquide. Citronellic acid ( $\geq 94 \%$ ) was supplied by SAFC. Titanium(IV)butoxide was purchased from Aldrich, and $\mathrm{LiAlH}_{4}$ was purchased from Merck. The catalyst precursor [(dtbpx)Pd(OTf)](OTf) was prepared according to ref. 9 . Deuterated solvents were supplied by Eurisotop. NMR spectra were recorded on a Varian Inova 400 and on a Bruker Avance 400 spectrometer. ${ }^{1} \mathrm{H}$ and ${ }^{13} \mathrm{C}$ chemical shifts were referenced to the solvent signals. DSC analyses were performed on a Netzsch Phoenix 204 F1 instrument with a heating and cooling rate of $30 \mathrm{~K} \mathrm{~min}^{-1}$. Data reported are from second heating cycles. GPC analyses were performed on a Polymer-Laboratories GPC220 instrument with refractive index detection, equipped with three PLgel Olexis columns in TCB at $160^{\circ} \mathrm{C}$ against linear polyethylene standards. Gas chromatographic analyses were performed using a Perkin-Elmer Clarus 500 instrument with an autosampler; equipped with a flame ionization detector (FID) and an Elite-Wax column (polyethylene glycol) of $30 \mathrm{~m}$ length, 0.32 $\mathrm{mm}$ inner diameter and $0.25 \mu \mathrm{m}$ film thickness. The temperature of the oven was kept at $100{ }^{\circ} \mathrm{C}$ for $1 \mathrm{~min}$, then heated from $100{ }^{\circ} \mathrm{C}$ to $300^{\circ} \mathrm{C}$ with a heating rate of $15^{\circ} \mathrm{C}$ per minute and was finally held at this temperature for 5 min. Injector and detector temperature were both $250^{\circ} \mathrm{C}$. The sample was injected via the auto sampler, the injection volume was set to $1 \mu \mathrm{L}$. Analysis of the retention times and peak areas were performed using the TotalChrom software (Perkin Elmer).

\section{General procedure for alkoxycarbonylation of citronellic acid}

The methoxycarbonylation reactions for screening purposes were carried out in $20 \mathrm{~mL}$ stainless steel, pressure reactors, equipped with a glass inlay and a magnetic stir bar. Temperature regulation was provided by a thermocouple, integrated into a heating block. All indicated temperatures refer to the temperature of the heating block. Prior to a carbonylation experiment, the reactor was evacuated and purged with argon several times. [(dtbpx)Pd(OTf)](OTf) (19 mg, $0.024 \mathrm{mmol}$ ) was weighed into a Schlenk tube under an inert atmosphere and dissolved in $10 \mathrm{~mL}$ of dry methanol. Citronellic acid $(0.95 \mathrm{~mL}, 6 \mathrm{mmol})$ was added and the reaction mixture was transferred into the pressure reactor. The reactor was closed, pressurized with carbon monoxide and then heated to the desired reaction temperature. After the desired reaction time, the reactor was cooled to room temperature and vented. The reaction mixture was filtered over a Buchner funnel to remove solid residues.

\section{Dimethyl 3,7-dimethylnonane-1,9-dioate (2)}

Methoxycarbonylation reactions on a preparative scale were carried out in a mechanically stirred $200 \mathrm{~mL}$ miniclave drive reactor with a glass inlay from Büchi Glas Uster. The reactor was equipped with a heating/cooling jacket supplied by a thermostat, such that the carbonylation temperature was controlled by means of a thermocouple dipping into the reaction mixture. Prior to a methoxycarbonylation experiment, the reactor was evacuated and purged with nitrogen several times. [(dtbpx)Pd(OTf)](OTf) (306 mg, $0.38 \mathrm{mmol}$ ) was weighed into a Schlenk tube under an inert atmosphere and dissolved in $120 \mathrm{~mL}$ of dry methanol. Citronellic acid (17.64 mL, $96 \mathrm{mmol}$ ) was added and the reaction mixture was transferred into the pressure reactor. The reactor was closed, pressurized with carbon monoxide to 30 
bar and then slowly heated to $80^{\circ} \mathrm{C}$. After six days, the reactor was cooled to room temperature and vented. The reaction mixture was filtered over a Buchner funnel to remove solid residues and the solvent was removed in vacuo. After two column chromatographies (PE-EE $=20: 1, R_{\mathrm{f}}=0.30$ and DCM-MeOH $=100: 1, R_{\mathrm{f}}=0.88$ ) dimethyl 3,7dimethylnonanedioate (2) was obtained as a colorless oil (16.34 g, 70\%). The side products methyl 3,7-dimethyloct-2enoate (5) $\left(R_{\mathrm{f}}=0.67\right)$, isomers thereof $\left(R_{\mathrm{f}}=0.60\right)$, and methyl 7-methoxy-3,7-dimethyloctanoate $(4)\left(R_{\mathrm{f}}=0.29\right)$ also could be isolated after the first column chromatography. The side product dimethyl 3-(4-methylpentyl)pentanedioate (3) could not be separated, but was enriched to a 1:10 mixture of $\mathbf{3}$ and $\mathbf{2}$ for NMR spectroscopic identification.<smiles>CC(CCCC(C)CC(=O)OI)CC(=O)OI</smiles>

${ }^{1} \mathrm{H}-\mathrm{NMR}\left(\mathrm{CDCl}_{3}, 25^{\circ} \mathrm{C}, 400 \mathrm{MHz}\right): 0.84\left(\mathrm{~d},{ }^{3} \mathrm{~J}_{\mathrm{H}-\mathrm{H}}=6.7 \mathrm{~Hz}, 6 \mathrm{H}, \mathrm{H}-5\right), 1.04-1.28(\mathrm{~m}, 6 \mathrm{H}, \mathrm{H}-6, \mathrm{H}-7), 1.80-1.89(\mathrm{~m}, 2 \mathrm{H}, \mathrm{H}-$ 4), $2.01\left(\mathrm{dd},{ }^{2} \mathrm{~J}_{\mathrm{H}-\mathrm{H}}=14.8 \mathrm{~Hz},{ }^{3} J_{\mathrm{H}-\mathrm{H}}=1.9 \mathrm{~Hz}\right)$ and $2.03\left(\mathrm{dd},{ }^{2} \mathrm{~J}_{\mathrm{H}-\mathrm{H}}=14.8 \mathrm{~Hz},{ }^{3} \mathrm{~J}_{\mathrm{H}-\mathrm{H}}=2.0 \mathrm{~Hz}\right)\left(2 \mathrm{H}, \mathrm{H}-3,3^{\prime}\right), 2.19\left(\mathrm{dd},{ }^{2} \mathrm{~J}_{\mathrm{H}-\mathrm{H}}=14.8\right.$ $\left.\mathrm{Hz},{ }^{3} \mathrm{~J}_{\mathrm{H}-\mathrm{H}}=1.4 \mathrm{~Hz}\right)$ and $2.21\left(\mathrm{dd},{ }^{2} \mathrm{~J}_{\mathrm{H}-\mathrm{H}}=14.8 \mathrm{~Hz},{ }^{3} \mathrm{~J}_{\mathrm{H}-\mathrm{H}}=1.5 \mathrm{~Hz}\right)\left(2 \mathrm{H}, \mathrm{H} 3,3^{\prime}\right), 3.57(\mathrm{~s}, 6 \mathrm{H}, \mathrm{H}-1)$.

${ }^{13} \mathrm{C}-\mathrm{NMR}\left(\mathrm{CDCl}_{3}, 25^{\circ} \mathrm{C}, 100 \mathrm{MHz}\right): 19.61$ and $19.69\left(\mathrm{C}-5,5^{\prime}\right), 24.16$ (C-7), 30.21 and 30.23 (C-4, 4'), 36.66 and 36.69 $\left(C-6,6^{\prime}\right), 41.50$ and $41.57\left(C-3,3^{\prime}\right), 51.23$ (C-1), 173.53 (C-2).

Elemental analysis: Calcd for $\mathrm{C}_{13} \mathrm{H}_{24} \mathrm{O}_{4}\left(244.17 \mathrm{~g} \mathrm{~mol}^{-1}\right): \mathrm{C}, 63.91 ; \mathrm{H}, 9.90 ; \mathrm{O}, 26.19$. Found: $\mathrm{C}, 63.90 ; \mathrm{H}, 9.74$. ESI-MS: $267.3 \mathrm{~m} / \mathrm{z}[\mathrm{M}+\mathrm{Na}]^{+}$.

\section{3,7-Dimethylnonane-1,9-diol (6)}

In a $250 \mathrm{~mL}$ round bottom flask, THF $(40 \mathrm{~mL})$ was cooled to $0{ }^{\circ} \mathrm{C}$ before $\mathrm{LiAlH}_{4}(0.77 \mathrm{~g}, 20.46 \mathrm{mmol})$ was slowly added. To this suspension, a solution of dimethyl 3,7-dimethylnonanedioate $(2.00 \mathrm{~g}, 8.18 \mathrm{mmol})$ in THF $(20 \mathrm{~mL})$ was added slowly. The reaction mixture was stirred at $70^{\circ} \mathrm{C}$ for $1 \mathrm{~h}$, and overnight at room temperature. After quenching with 0.4 $\mathrm{mL}$ of $\mathrm{H}_{2} \mathrm{O}, 1.0 \mathrm{~mL}$ of $2 \mathrm{M} \mathrm{NaOH}$ and another $1.2 \mathrm{~mL}$ of $\mathrm{H}_{2} \mathrm{O}$, the mixture was stirred for $1 \mathrm{~h}$, concentrated in vacuo and dissolved in THF $(80 \mathrm{~mL})$. The metal salts were filtered off. After column chromatography $\left(\mathrm{DCM} / \mathrm{EE}=1 / 1, R_{\mathrm{f}}=0.40\right)$ 3,7-dimethylnonane-1,9-diol (6) was isolated as a colorless oil in $99 \%$ purity $(1.23 \mathrm{~g}, 80 \%)$.<smiles>CC(CCO)CCCC(C)CCO</smiles>

${ }^{1} \mathrm{H}-\mathrm{NMR}\left(\mathrm{CDCl}_{3}, 25^{\circ} \mathrm{C}, 400 \mathrm{MHz}\right): 0.89\left(\mathrm{~d},{ }^{3} \mathrm{~J}_{\mathrm{H}-\mathrm{H}}=6.5 \mathrm{~Hz}, 6 \mathrm{H}, \mathrm{H}-4\right), 1.09-1.42(\mathrm{~m}, 10 \mathrm{H}, \mathrm{H}-2, \mathrm{H}-5, \mathrm{H}-6, \mathrm{OH}), 1.54-1.65$ ( $\mathrm{m}, 4 \mathrm{H}, \mathrm{H}-2, \mathrm{H}-3), 3.62-3.73(\mathrm{~m}, 4 \mathrm{H}, \mathrm{H}-1)$. This agrees with reported data. $\frac{14}{4}$

${ }^{13} \mathrm{C}-\mathrm{NMR}\left(\mathrm{CDCl}_{3}, 25^{\circ} \mathrm{C}, 100 \mathrm{MHz}\right): 19.76$ and 19.82 (C-4, $\left.4^{\prime}\right), 24.35$ (C-6), 29.49 and 29.64 (C-3, 3'), 37.30 and 37.50 $\left(\mathrm{C}-5,5^{\prime}\right), 40.06$ and $40.17\left(\mathrm{C}-2,2^{\prime}\right), 61.31$ and $61.36\left(\mathrm{C}-1,1^{\prime}\right)$.

Elemental analysis: Calcd for $\mathrm{C}_{11} \mathrm{H}_{24} \mathrm{O}_{2}\left(188.31 \mathrm{~g} \mathrm{~mol}^{-1}\right)$ : C, 70.16; $\mathrm{H}, 12.85 ; \mathrm{O}, 16.99$. Found: $\mathrm{C}, 69.75 ; \mathrm{H}, 12.77$.

\section{Poly[1,9-(3,7-dimethyl)nonadiyl-1,9-(3,7-dimethyl)nonanedioate] (7)}

Polycondensation was carried out in a $100 \mathrm{~mL}$ two-necked Schlenk tube equipped with an overhead stirrer. Efficient mixing of the highly viscous polymer melt was achieved using a helical agitator. Dimethyl 3,7-dimethylnonanedioate (2) (0.59 g, $2.42 \mathrm{mmol}$ ) and 3,7-dimethylnonane-1,9-diol (6) (0.50 g, $2.66 \mathrm{mmol})$ were heated to $80^{\circ} \mathrm{C}$ under a nitrogen atmosphere. $\mathrm{Ti}(\mathrm{OBu})_{4}(3.3 \mathrm{mg}, 9.7 \mu \mathrm{mol})$ in toluene $(0.11 \mathrm{~mL})$ was added and the temperature was raised to $170{ }^{\circ} \mathrm{C}$ within 8 hours at a dynamic vacuum of 40 mbar pressure. Finally, the reaction mixture was stirred for 16 hours at 170 ${ }^{\circ} \mathrm{C}$ and $40 \mathrm{mbar}$. The polymer was cooled to $120^{\circ} \mathrm{C}$ and stirred at this temperature with toluene $(2 \mathrm{~mL})$ for one hour. After the addition of methanol $(20 \mathrm{~mL})$, the highly viscous polymer was decanted and dried in vacuo.

\section{Acknowledgements}

We thank Lars Bolk for DSC and GPC measurements, and Malin Bein for assistance with chiral HPLC and chiral GC. NMR measurements by Inigo Göttker-Schnetmann and Philipp Roesle are acknowledged. 


\section{Notes and references}

1. (a) P. W. N. M. van Leeuwen, C. Claver , J. A. McCleverty and T. J. Meyer, Comprehensive Coordination Chemistry II , Elsevier, Oxford, 2004, vol. 9, 141-206 . (b) P. W. N. M. van Leeuwen Homogeneous Catalysis: Understanding the Art , Kluwer Academic Publishers, Dordrecht, 2004,.

2. (a) J. Mane, J. J. Chanot, P. Jaunky and C. Marin, WO , 2008/009841 A1, 2008 . (b) M. Gottardo , A. Scarso, S. Paganelli and G. Strukul , Adv. Synth. Catal., 2010, 352 , $2251-2262$. (c) H. J. V. Barros, J. G. da Silva , C. C. Guimarães, E. N. dos Santos and E. V. Gusevskaya, Organometallics, 2008, 27, 4523-4531 . (d) C. G. Vieira, E. N. dos Santos and E. V. Gusevskaya , Appl. Catal., A, 2013, 466 , $208-215$

3. (a) C. Benedek, L. Prókai , S. Tõrös and B. Heil , J. Mol. Catal. A: Chem., 2001, 165 , 15 -21 . (b) A. Behr , L. Johnen , A. Wintzer , A. Willstumpf and M. Dinges , Catal. Sci. Technol., 2013, 3, $1573-1578$.

4. H. J. Arpe Industrial Organic Chemistry, Wiley-VCH, Weinheim, 2010,

5. (a) L. A. van der Veen, P. C. J. Kamer and P. W. N. M. van Leeuwen, Angew. Chem., Int. Ed., 1999, 38, 336 338 . (b) D. Selent, D. Hess, K. D. Wiese, D. Röttger, C. Kunze and A. Börner, Angew. Chem., Int. Ed., 2001, 40, 1696 -1698 . (c) H. Klein , R. Jackstell , K. D. Wiese , C. Borgmann and M. Beller, Angew. Chem., Int. Ed., 2001, 40, 3408 -3411 . (d) K. Y. Ghebreyessus and R. J. Angelici , Organometallics, 2006, 25, 3040 - 3044 . (e) Y. Yuki , K. Takahashi, Y. Tanaka and K. Nozaki , J. Am. Chem. Soc., 2013, 135, $17393-17400$.

6. (a) R. I. Pugh, E. Drent and P. G. Pringle, Chem. Commun., 2001, 1476 -1477 . (b) C. Jiménez-Rodriguez , D. F. Foster , G. R. Eastham and D. J. Cole-Hamilton , Chem. Commun., 2004, $1720-1721$. (c) C. JiménezRodriguez , G. R. Eastham and D. J. Cole-Hamilton, Inorg. Chem. Commun., 2005, 8, 878 -881 . (d) P. Roesle , C. J. Dürr , H. M. Möller , L. Cavallo, L. Caporaso and S. Mecking , J. Am. Chem. Soc., 2012, 134 , $17696-17703$.

7. (a) M. Firdaus and M. A. R. Meier, Green Chem., 2013, 15, 370-380 . (b) P. A. Wilbon, F. Chu and C. Tang , Macromol. Rapid Commun., 2013, 34, 8-37 . (c) J. M. Bolton, M. A. Hillmyer and T. R. Hoye , ACS Macro Lett., 2014, 3 , 717 -720 . (d) M. Bähr , A. Bitto and R. Mülhaupt, Green Chem., 2012, 14, 1447 -1454 . (e) E. Breitmaier Terpenes, Wiley-VCH, Weinheim, 2006, .

8. K. Bauer and D. Garbe, Common Fragrance and Flavor Materials: Preparation, Properties and Uses, VCH, Weinheim, 1985, .

9. F. Stempfle, D. Quinzler, I. Heckler and S. Mecking, Macromolecules, 2011, 44, $4159-4166$

10. (a) N. Carr , B. J. Dunne, A. G. Orpen and J. L. Spencer , J. Chem. Soc., Chem. Commun., 1988, 926 -928 . (b) W. Clegg , G. R. Eastham , M. R. J. Elsegood , R. P. Tooze , X. L. Wang and K. Whiston , Chem. Commun., 1999, 1877 1878 .

11. (a) R. C. Bohley, G. B. Jacobsen, H. L. Pelt , B. J. Schaart, M. Schenk and D. A. G. van Oeffelen, WO , 92/10450, 1992 . (b) M. J.-L. Tschan , E. J. Garcia-Suárez , Z. Freixa , H. Launay , H. Hagen , J. Benet-Buchholz and P. W. N. M. van Leeuwen , J. Am. Chem. Soc., 2010, 132, $6463-6473$.

12. J. T. Christl , P. Roesle , F. Stempfle, G. Müller , L. Caporaso, L. Cavallo and S. Mecking, ChemSusChem, 2014, .

13. $\mathrm{LiAlH}_{4}$ in $\mathrm{THF}$ was used in these laboratory scale experiments. Note that catalytic hydrogenation offers itself as an alternative

14. P. Gramatica, P. Manitto and L. Poli , J. Org. Chem., 1985, 50 , 4625 -4628 


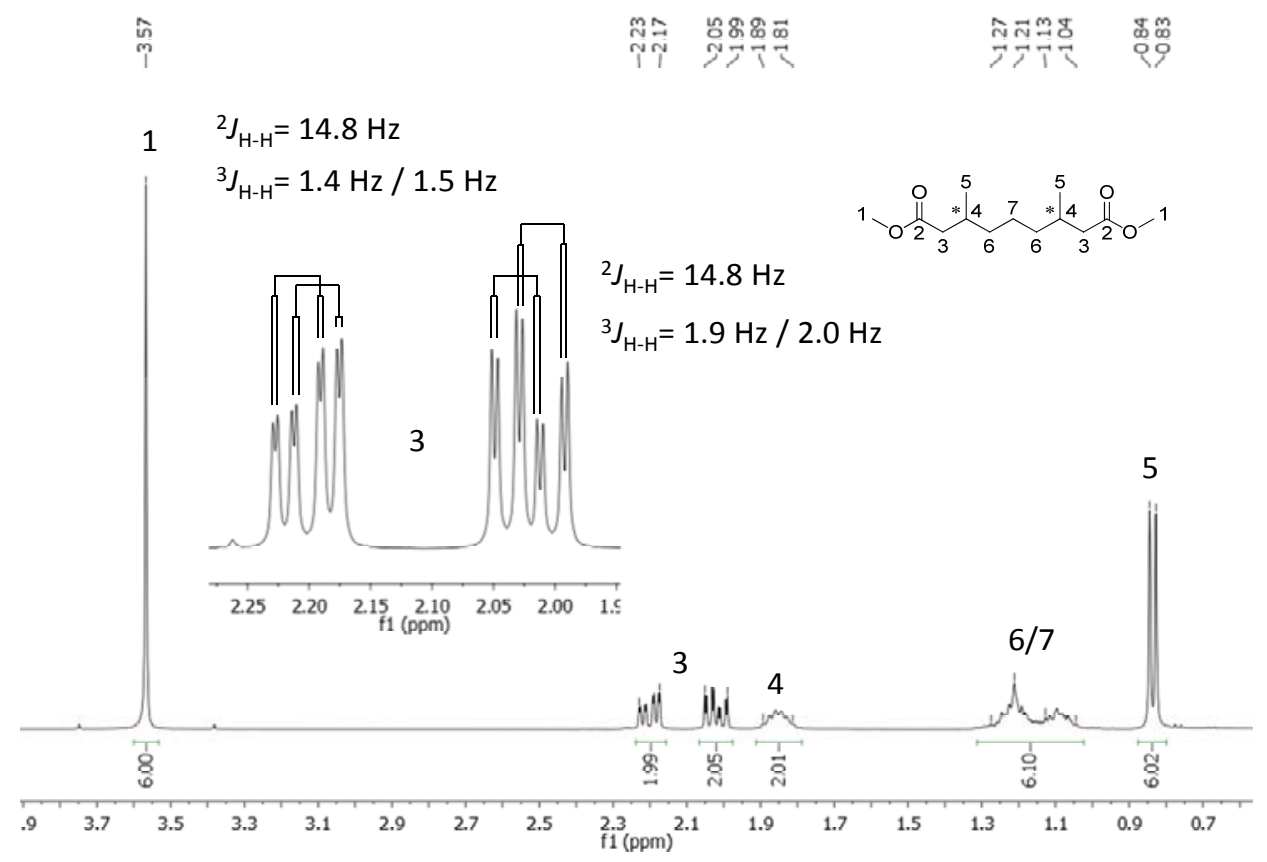

Figure S1: ${ }^{1} \mathrm{H}$ NMR spectrum (400 $\mathrm{MHz}, \mathrm{CDCl}_{3}, 25^{\circ} \mathrm{C}$ ) of dimethyl 3,7-dimethylnonane-1,9-dioate (2).

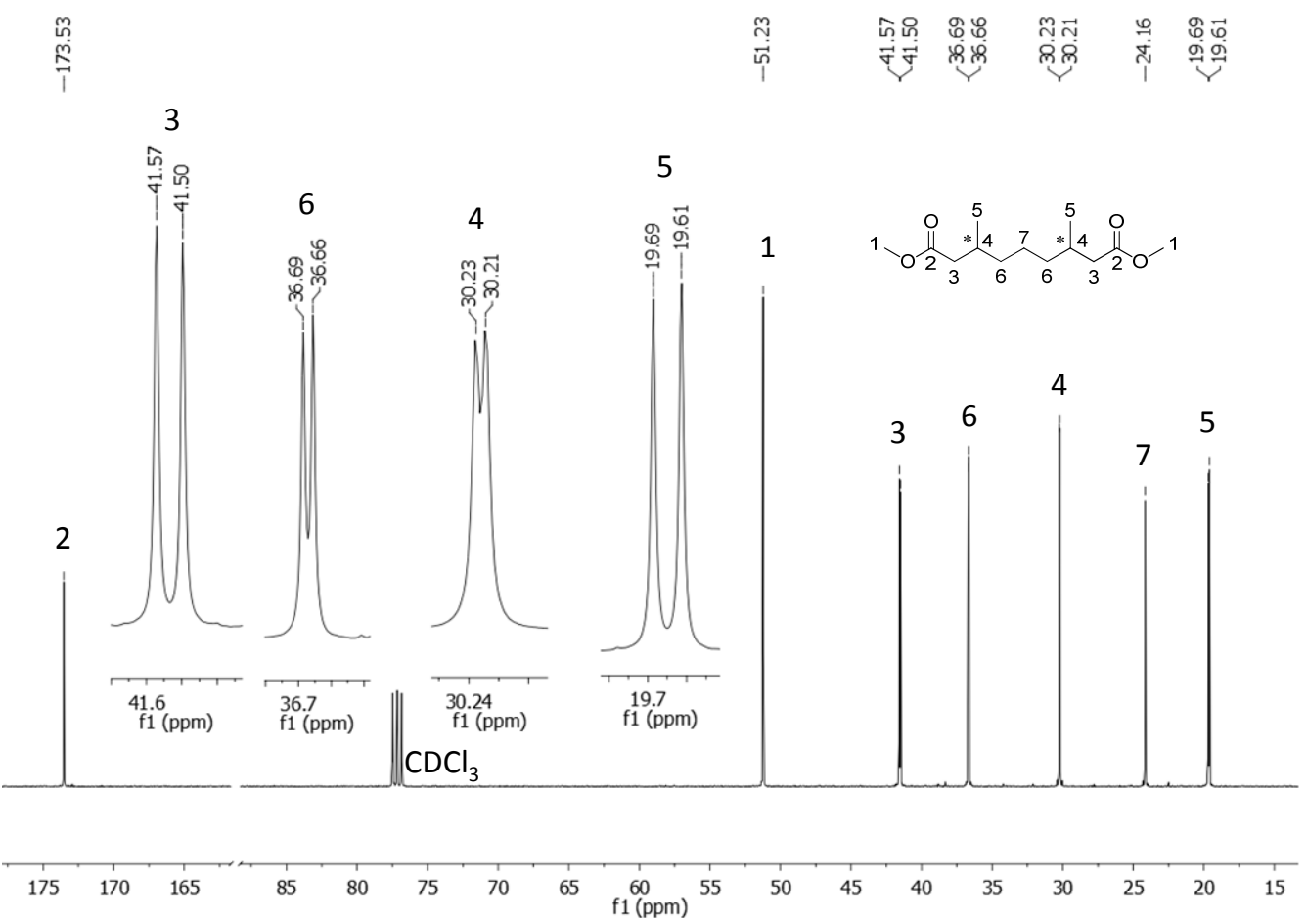

Figure S2: ${ }^{13} \mathrm{C}\left\{{ }^{1} \mathrm{H}\right\}$ NMR spectrum $\left(100 \mathrm{MHz}, \mathrm{CDCl}_{3}, 25{ }^{\circ} \mathrm{C}\right)$ of dimethyl 3,7-dimethylnonane-1,9-dioate (2). 


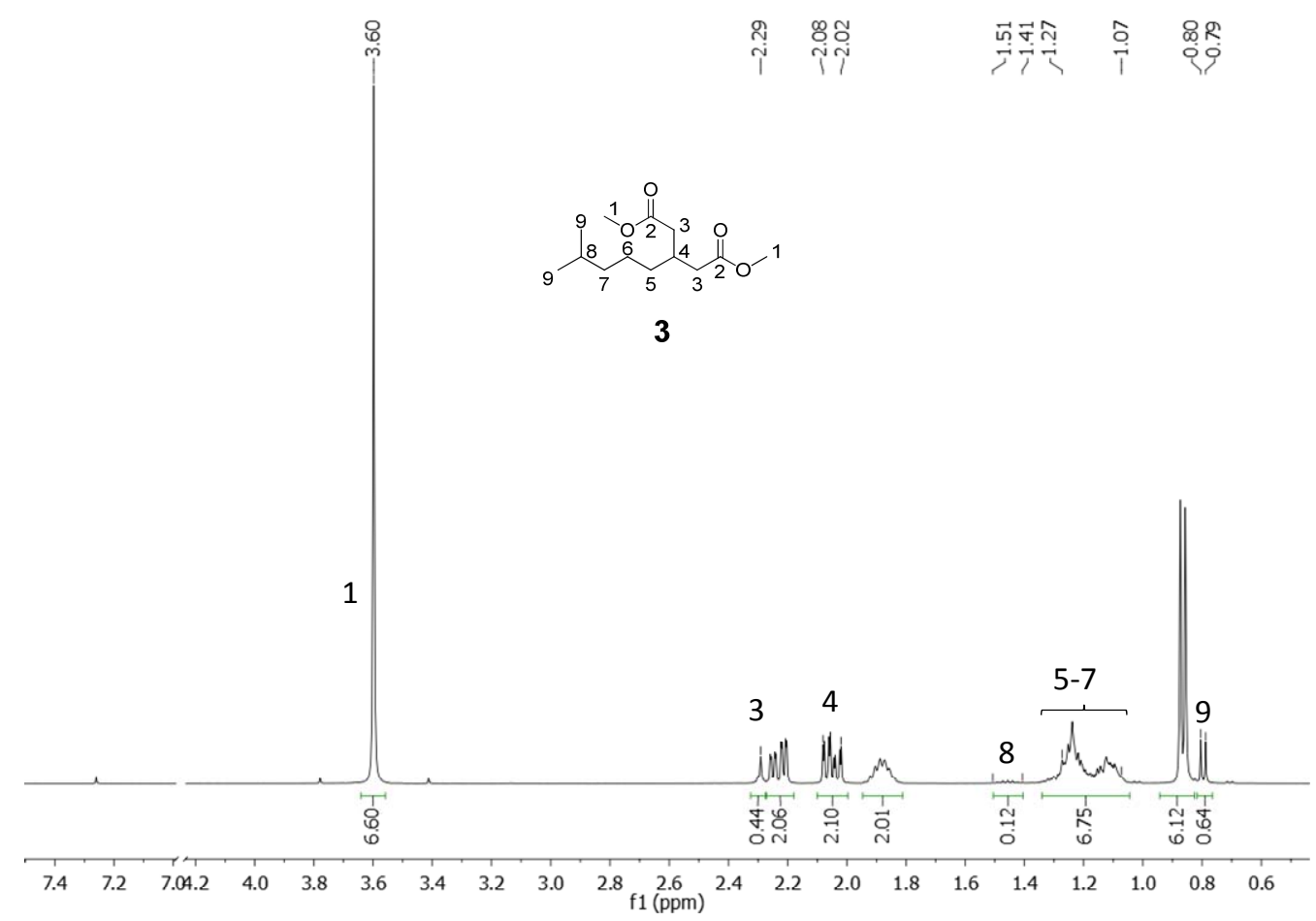

Figure S3: ${ }^{1} \mathrm{H}$ NMR spectrum ( $400 \mathrm{MHz}, \mathrm{CDCl}_{3}, 25^{\circ} \mathrm{C}$ ) of enriched dimethyl 3-(4-methylpentyl)pentanedioate (3) with dimethyl 3,7-dimethylnonane1,9-dioate (2) (ratio 1:10).

$\underset{\substack{n \\ \stackrel{m}{i}}}{\stackrel{c}{i}}$

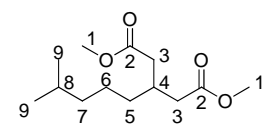

3

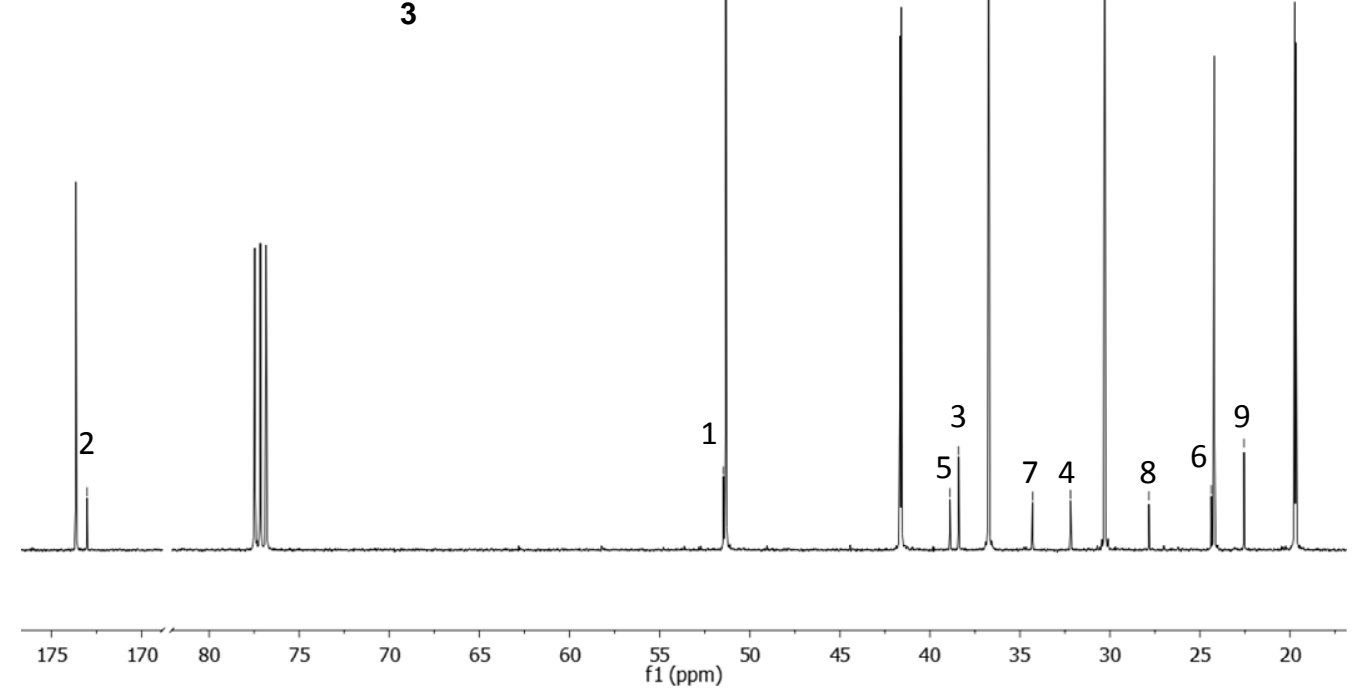

Figure S4: ${ }^{13} \mathrm{C}\left\{{ }^{1} \mathrm{H}\right\}$ NMR spectrum $\left(100 \mathrm{MHz}, \mathrm{CDCl}_{3}, 25^{\circ} \mathrm{C}\right)$ of enriched dimethyl 3-(4-methylpentyl)pentanedioate (3) with dimethyl 3,7dimethylnonane-1,9-dioate (2) (ratio 1:10). 

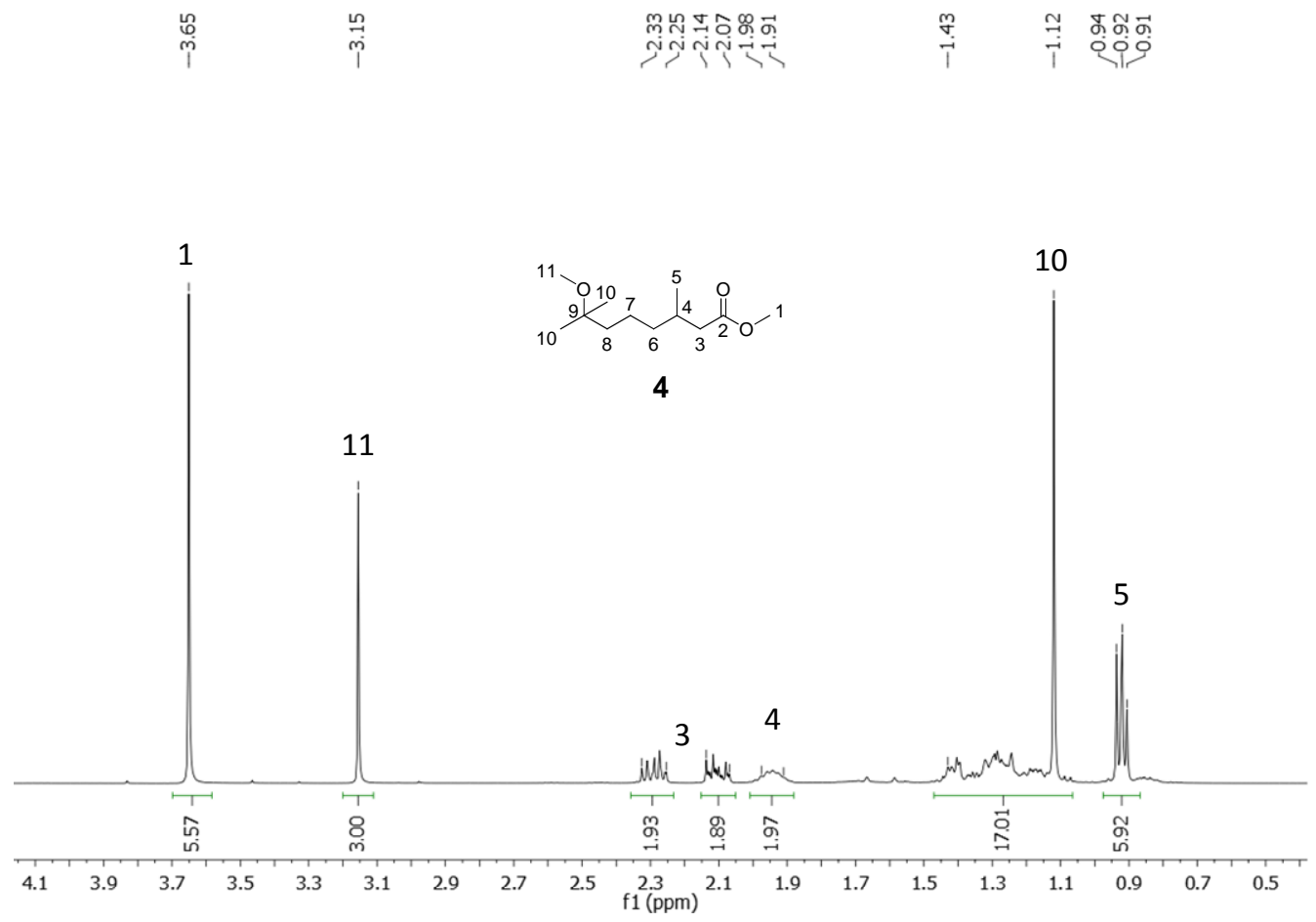

Figure S5: ${ }^{1} \mathrm{H}$ NMR spectrum (400 $\mathrm{MHz}, \mathrm{CDCl}_{3}, 25^{\circ} \mathrm{C}$ ) of enriched methyl 7-methoxy-3,7-dimethyloctanoate (4) with dimethyl 3,7-dimethylnonane-1,9dioate (2) (ratio 3:1).

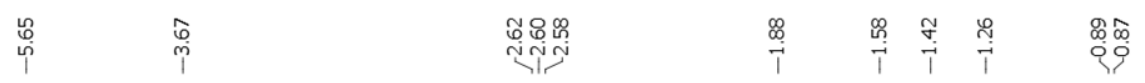

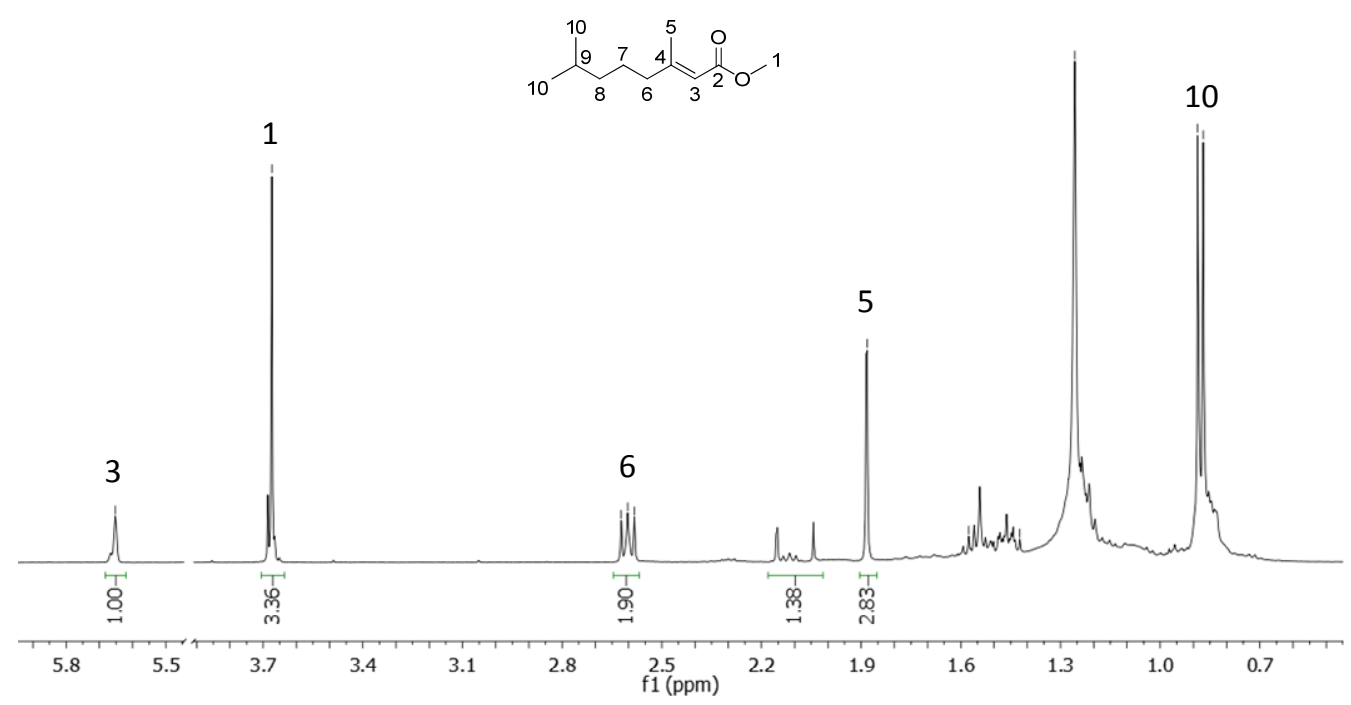

Figure S6: ${ }^{1} \mathrm{H}$ NMR spectrum (400 MHz, $\left.\mathrm{CDCl}_{3}, 25^{\circ} \mathrm{C}\right)$ of methyl 3,7-dimethyloct-2-enoate (5). 


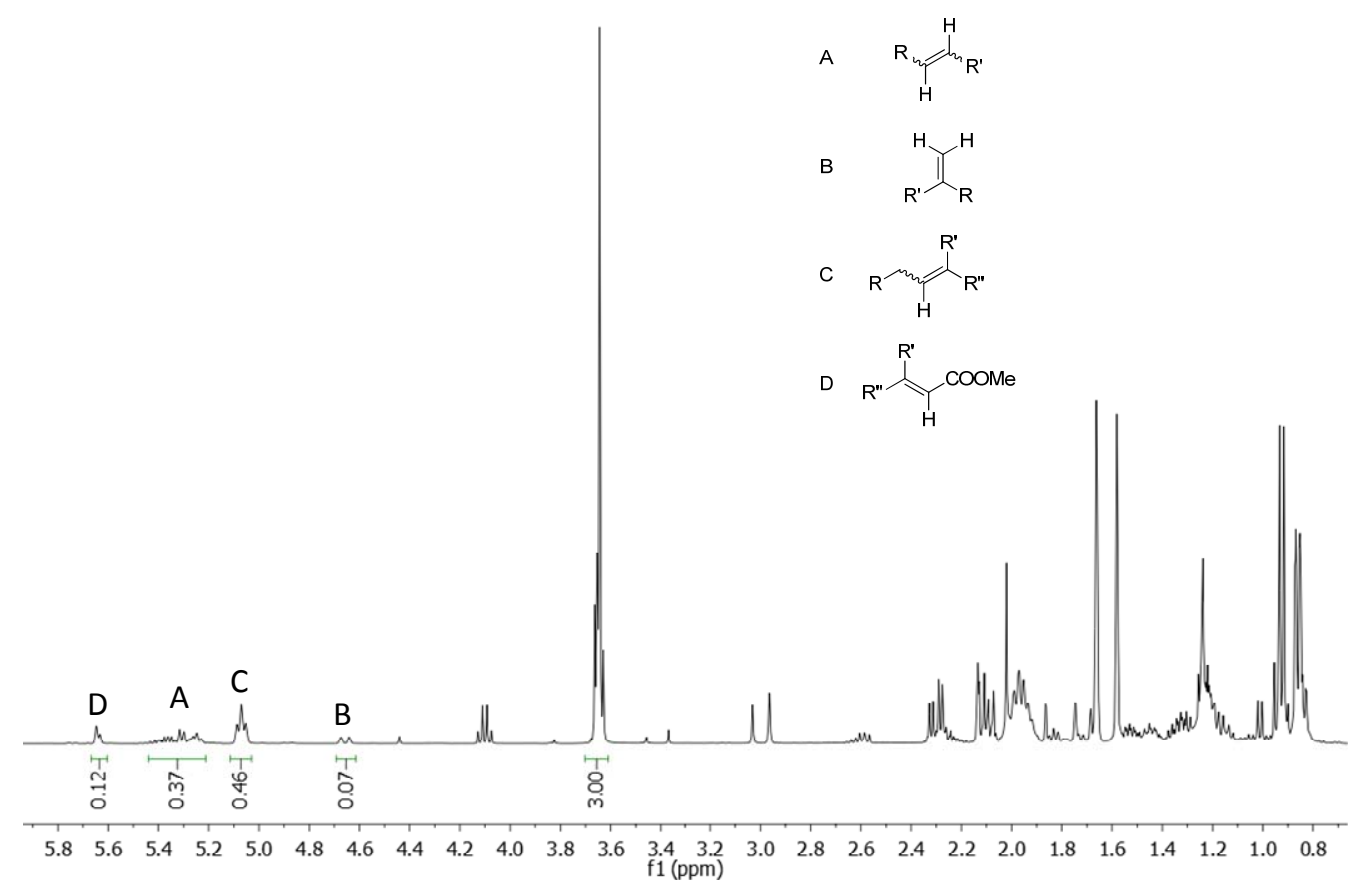

Figure S7: ${ }^{1} \mathrm{H}$ NMR spectrum ( $400 \mathrm{MHz}, \mathrm{CDCl}_{3}, 25^{\circ} \mathrm{C}$ ) of double bond isomers of the (esterified) starting material (depleted in 5 to facilitate observation of all isomers).

$\underset{\substack{m \\ i}}{\stackrel{\infty}{p}}$

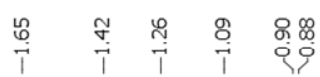

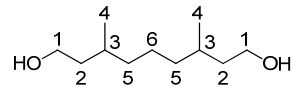

4

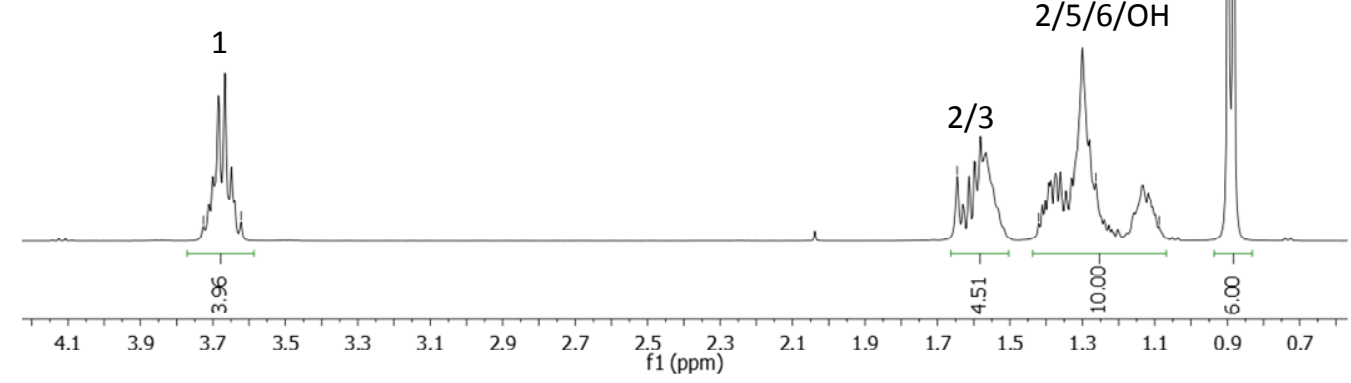

Figure S8: ${ }^{1} \mathrm{H}$ NMR spectrum (400 MHz, $\left.\mathrm{CDCl}_{3}, 25^{\circ} \mathrm{C}\right)$ of 3,7-dimethylnonane-1,9-diol (6). 

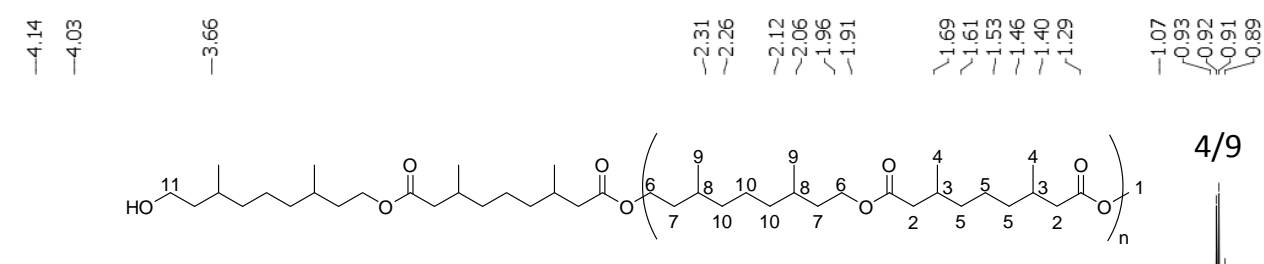

$4 / 9$

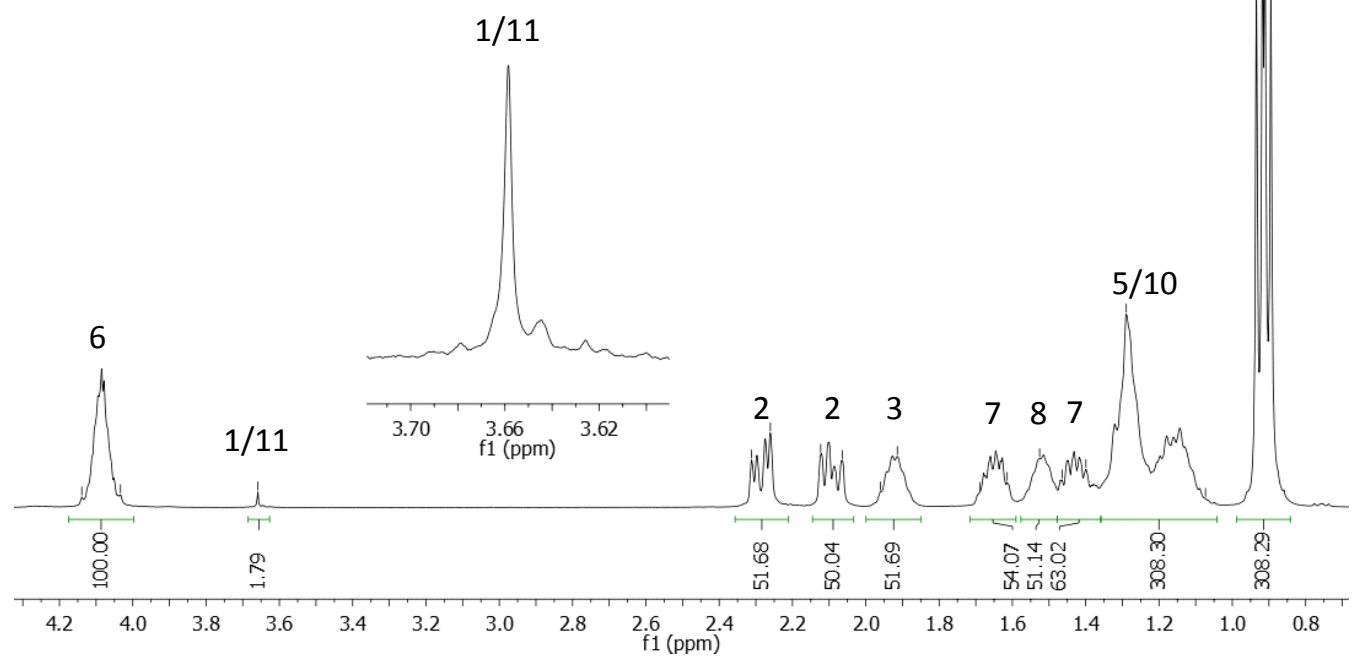

Figure S9: ${ }^{1} \mathrm{H}$ NMR spectrum (400 MHz, $\left.\mathrm{C}_{2} \mathrm{D}_{2} \mathrm{Cl}_{4}, 25^{\circ} \mathrm{C}\right)$ of poly[1,9-(3,7-dimethyl)nonadiyl-1,9-(3,7-dimethyl)nonanedioate] (7). Insert shows enlargement of the end group region.

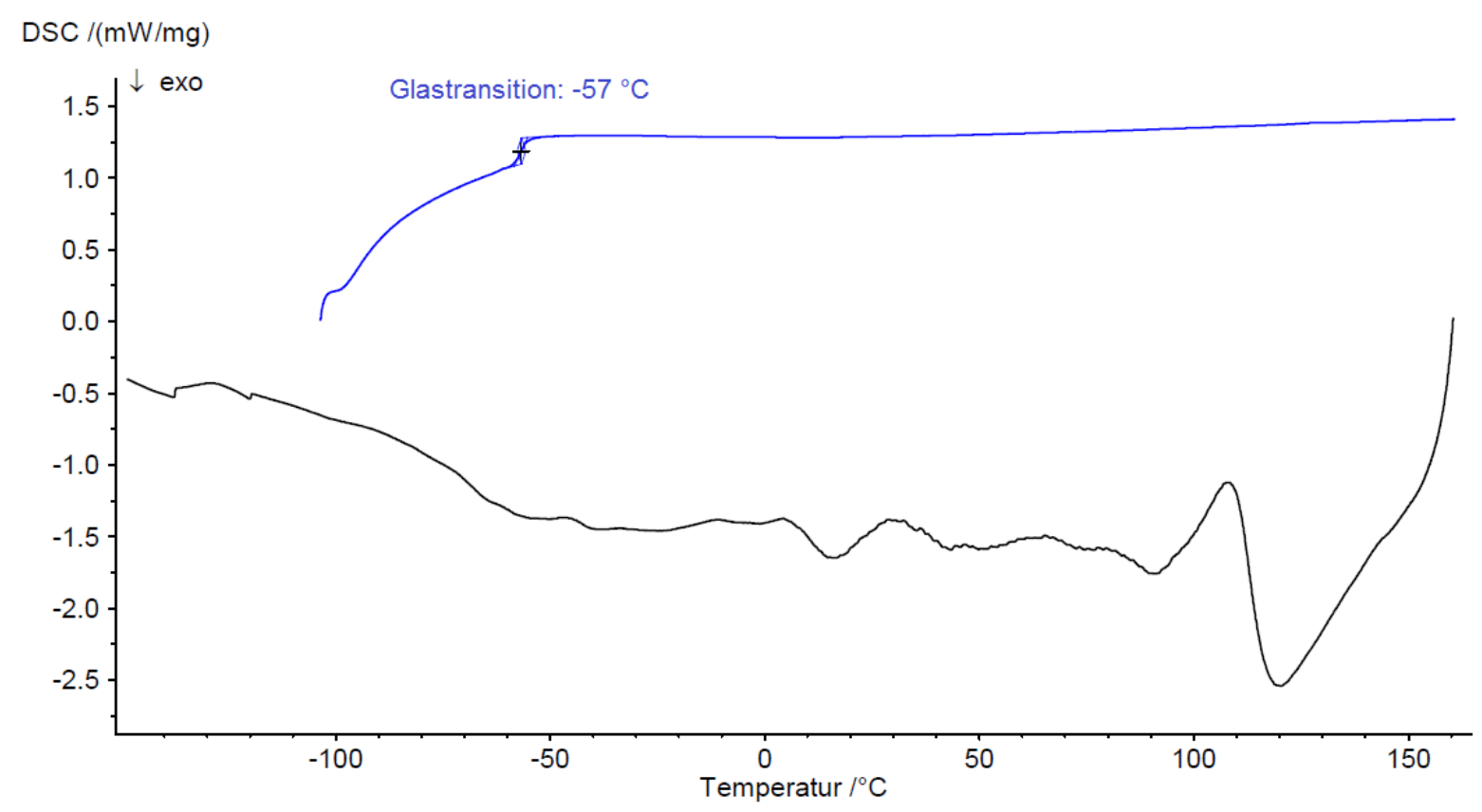

Figure S10: DSC trace of poly[1,9-(3,7-dimethyl)nonadiyl-1,9-(3,7-dimethyl)nonanedioate] (7). 
MW Averages

$\begin{array}{llll}\text { Mp: } 16965 & \text { Mn: } 8341 & \text { Mv: } 19015 & \text { Mw: } 21474 \\ \text { Mz: } 45223 & M z+1: 84223 & \text { PD: } 25745 & \end{array}$

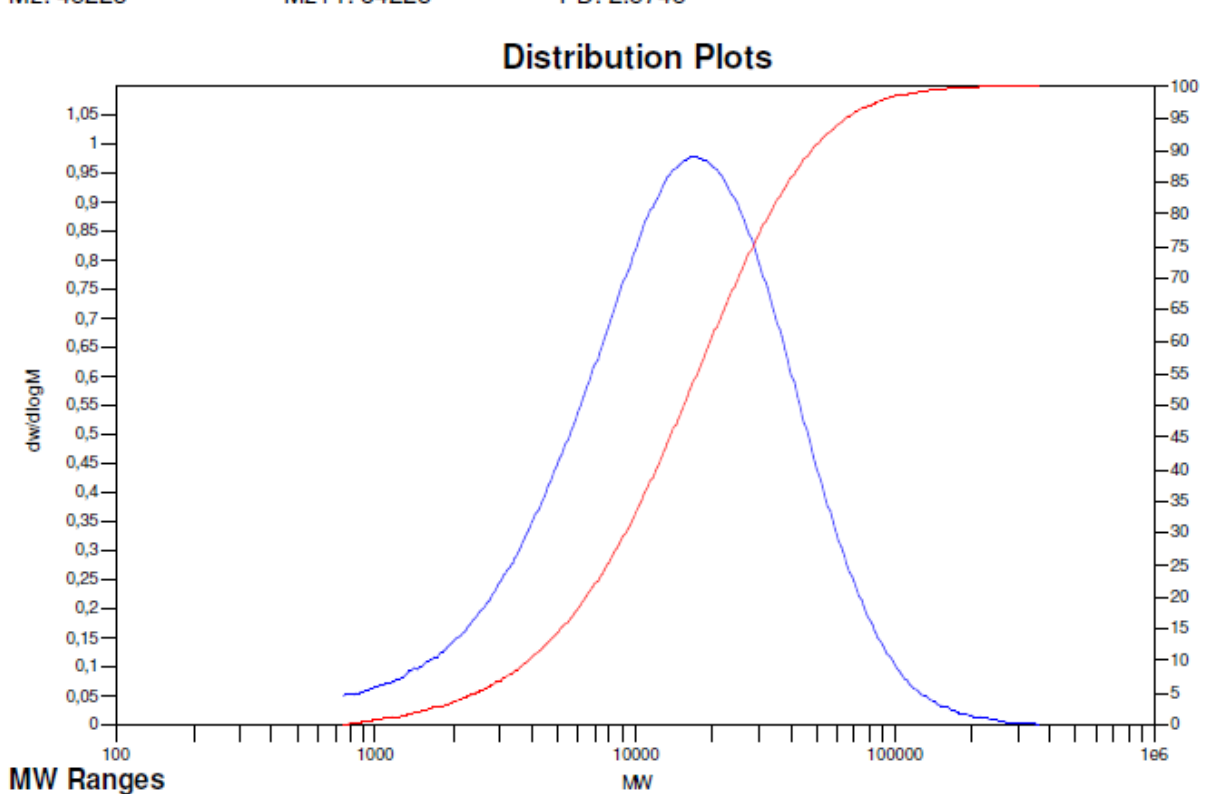

Figure S11: GPC trace of poly[1,9-(3,7-dimethyl)nonadiyl-1,9-(3,7-dimethyl)nonanedioate] (7) (TCB: $160{ }^{\circ} \mathrm{C}$, vs. PE standards). 